\title{
Sistem Penentuan Penginapan dengan Metode Promethee
}

\author{
Novita Ranti Muntiari ${ }^{1}$, Sunardi ${ }^{2}$, Abdul Fadlil ${ }^{3}$ \\ ${ }^{1}$ Program Studi Magister Teknik Informatika, Universitas Ahmad Dahlan,Yogyakarta \\ ${ }^{2,3}$ Program Studi Teknik Elektro, Universitas Ahmad Dahlan, Yogyakarta \\ 1novita1907048010@webmail.uad.ac.id,2sunardi@mti.uad.ac.id, ${ }^{3}$ fadlil@mti.uad.ac.id
}

\begin{abstract}
Lodging Determination System with Promethee Method. Every person who travels to a place for a period of days requires lodging with certain criteria and different possibilities for each person. The problem lies in determining the desired lodging recommendations because there are too many choices and various criteria. This study conducted a search for lodging in Yogyakarta with criteria for distance, price, class of lodging, room facilities and supporting facilities. The Promethee method is used to get the rankings of each alternatef by calculating the weights for each criterion. Alternative values desired by visitors are processed to find the value of criteria and preference criteria to then be calculated leaving flow and entering flow to get net flow. This research produces a ranking of data that has been tested using a system with the highest net flow value is 0.5 ie alternative lodging 1 with this is prioritized according to the criteria desired by visitors.
\end{abstract}

Keywords: Lodging, Promethee, Decision Support System

\begin{abstract}
Abstrak. Setiap orang yang berpergian ke suatu tempat dengan jangka waktu berhari-hari membutuhkan penginapan dengan kriteria tertentu dan kemungkinan berbeda untuk setiap orang. Permasalahannya terletak pada penentuan rekomendasi penginapan yang diinginkan karena terlalu banyak pilihan dan berbagai kriteria. Penelitian ini melakukan pencarian penginapan di Yogyakarta dengan kriteria jarak, harga, kelas penginapan, fasilitas kamar dan fasilitas pendukung. Metode Promethee digunakan untuk mendapatkan rangking dari masing-masing alternatef dengan memperhitungkan bobot untuk setiap kriteria. Nilai alternatif yang diinginkan pengunjung diproses untuk mencari nilai kriteria dan preferensi kriteria untuk kemudian dihitung leaving flow dan entering flow untuk mendapatkan net flow. Peneltian ini menghasilkan rangking dari data yang telah diuji menggunakan sistem dengan nilai net flow tertinggi adalah 0,5 yaitu alternatif penginapan 1 diprioritaskan sesuai dengan kriteria yang diinginkan oleh pengunjung.
\end{abstract}

Kata Kunci: Penginapan, Promethee, Sistem Pendukung Keputusan

\section{PENDAHULUAN}

Teknologi di era saat ini semakin berkembang dan banyak digunakan dalam membantu pekerjaan manusia. Teknologi dapat mempermudah dan mempercepat pekerjaan secara manual menjadi lebih sistematis. Aplikasi merupakan salah satu teknologi yang semakin berkembang. Setiap orang yang berpergian ke suatu tempat dengan jangka waktu berhari-hari membutuhkan penginapan dengan kriteria tertentu dan kemungkinan berbeda untuk setiap orang. Permasalahannya terletak pada penentuan rekomendasi penginapan yang diinginkan karena terlalu banyak pilihan, dengan fasilitas, jarak, kelas penginapan atau harga yang berbeda.
Sistem Pendukung Keputusan (SPK) atau Decision Support System (DSS) merupakan sistem berbasis komputer yang ditujukan untuk membantu pengambil keputusan dalam memanfaatkan data dan model tertentu untuk memecahkan berbagai persoalan yang bersifat semi terstruktur dan tidak terstruktur (Gusrianty et al., 2019)(Pramudhita, 2017)(Wardhani \& Nur, 2017). Beberapa model SPK antara lain Simple Additive Weighting (SAW), Analityc Hierarchy Process (AHP), Profile Matching, Technique for Others Reference by Similarity to Ideal Solution (TOPSIS), dan Weighted Product(WP) (Umar, Sunardi, et al., 2018)(Aprilia Triase; Sriani, Sriani, 2017)(Imandasari \& Windarto, 2017). Beberapa penelitian yang terkait dengan 
penentuan penginapan diantaranya metode Promethee untuk pemilihan hotel bintang lima terbaik di Kota Medan (Pasaribu, 2019) dengan tujuh kritera, yaituprice list, fasilitas, kenyamanan, tata letak, akses keluar masuk, keamanan, dan pelayanan. Pada tahap awal dilakukan pembobotan dalam melakukan pemilihan. Hasil dari perhitungan menggunakan Promethee diperoleh nilai rangking hotel berdasarkan karakter net flow. Penelitian sebelumnya (Larasati et al., 2019) telah membuat pemilihan hotel menggunakan metode $A H P$ untuk menghitung bobot atau prioritas setiap kriteria dan Promethee untuk menghitung alternatif dengan empat kriteria yaitu bintang, fasilitas, harga, dan strategis. Hasil dari penelitian adalah rekomendasi hotel yang sesuai kriteria yang diinginkan wisatawan.

Penelitian lain adalah pemilihan penginapan di Kota Bengkulu menggunakan metode $S A W$ dengan empat kriteria, yaitu harga, lokasi, kelas, dan fasilitas. Hasil dari penelitian adalah rangking penginapan (Ternando et al., 2018). Metode AHPpada empat kriteria yang digunakan, yaitu lokasi, harga, fasilitas kamar, dan fasilitas pendukung melalui multi-level kriteria dapat menangani kebutuhan hotel yang lebih spesifik dan detail sehingga memberikan hasil keputusan yang lebih optimal (Sabrina, 2017).

Penelitian ini menggunakan metode Promethee karena mudah diterapkan dibanding dengan metode lain untuk menuntaskan masalah multikriteria dan penentuan urutan (prioritas). Metode ini mampu mengakomodir kriteria pemilihan yang bersifat kuantitatif dan kualitatif.Metode Prometheedigunakan untuk memperoleh rangking dari masing-masing alternatif untuk mencari penginapan di Yogyakarta, yang hasilnya akan menentukan penginapan yang sesuai dengan kriteria yang diinginkan. Kriteria yang digunakan adalah jarak, harga, kelas penginapan, fasilitas kamar, dan fasilitas pendukung. Penelitian ini menggunakan bahasa pemrograman Visual Basic yang sangat diminati dalam SPK karena bahasa dan perintah skrip mudah dipahami. Selain itu, pemrograman Java juga mendukung tipe pemrograman yang terstruktur dan berorientasi objek. Dalam beberapa penelitianbisa dilihat dari penggunaan tipe diagram alir(Umar et al., 2017).

Metode Promethee merupakan metode penentuan alternatif dalam menganalisis multikriteria karena sederhana dan efisien. Kriteria yang telah dipilih menggunakan metode ini menghasilkan alternatif perangkingan. Penentuan alternatif dengan metode Promethee dilakukan melalui beberapa tahapan, yaitu(Anjasmaya \& Andayani, 2018)(Widyastuti et al., 2019)(Sofhian et al., 2016): menentukan alternatif yang diinginkan, menentukan setiap kriteria, tipe-tipe preferensi(Yudha et al., 2016), Input nilai alternatif terhadap kriteria dan baca bobot kriteria(Ayu Septiana Sari, Jumadil Nangi, 2016), kriteria memaksimalkan ditunjukkan di persamaan (1), kriteria minimum ditunjukkan di persamaan (2), menghitung nilai preferensi (Anjasmaya \& Andayani, 2018)(Hidayat, 2016), menghitung indeks preferensi kriteria ditunjukkan persamaan (3), entering flowditunjukkan persamaan (4)(Ningsih \& Windarto, 2018), leaving flow ditunjukkan persamaan (5), dan net flow ditunjukkan persamaan (6)(Mesran et al., 2019).

Penilaian maksimal dan minimum dari nilai bobot tiap alternatif dan kriteria sesuai dengan pengunjung inginkan.

$$
\begin{aligned}
& P(d)=\left\{\begin{array}{l}
0 \text { jika } d=0 \\
1 \text { jika } d \neq 0
\end{array} \ldots . . .(1)\right. \\
& P(d)=\left\{\begin{array}{l}
0 \text { jika } d \geq 0 \\
1 \text { jika } d<0 . . . . .(2)
\end{array}\right.
\end{aligned}
$$

$\mathrm{P}(\mathrm{d})$ adalah nilai bobot tiap alternatif dan kriteria.

Indeks preferensi kriteria menentukan jumlah nilai maksimal dan minimum kriteria-kriteria yang ada.

$$
\pi\left(A_{j}, A_{k}\right)=\sum_{i=1_{\in} A}^{n} \pi P_{i}\left(A_{j}, A_{k}\right), \forall A_{j}, A_{k}
$$

Keterangan

$\mathrm{A}_{\mathrm{j}}, \mathrm{A}_{\mathrm{k}} \quad=$ Alternatif 
$\mathrm{P}_{\mathrm{i}} \quad=$ Preferensi kriteria

$\mathrm{n} \quad=$ Banyaknya kriteria,$i=1$ dimulai dari 1

$\pi\left(A_{j}, A_{k}\right) \quad=$ Nilai preferensi kriteria

Entering flowadalah nilai yang didapat dari penjumlahan nilai indeks preferensi kriteria perkolom dari setiap alternatif kriteria.

$$
\Phi^{-}\left(A_{j}\right)=\frac{1}{n-1} \sum_{k=1}^{n} \pi\left(A_{j}, A_{k}\right)
$$

Leaving flowadalah nilai yang didapat dari penjumlahan nilai indeks preferensi kriteria perbaris dari setiap alternatif kriteria.

$$
\Phi^{+}\left(A_{j}\right)=\frac{1}{n-1} \sum_{k=1}^{n} \pi\left(A_{k}, A_{j}\right)
$$

Net flowadalah nilai yang didapat dari penjumlahan nilai leaving flow dikurang nilai entering flow. Nilai net flow yang digunakan untuk perhitungan hasil akhir menentukan rangking.

$$
\Phi\left(A_{j}\right)=\Phi^{+}\left(A_{j}\right)-\Phi^{-}\left(A_{j}\right)
$$

Metode Promethee melakukan dua perangkingan yaitu (S, Gde Iwan Widnyana, 2018):

1. Nilai entering flow dan leaving flow menghasilkan perangkingan parsial.

2. Nilai net flow menghasilkan perangkingan lengkap atau komplit.

\section{METODE PENELITIAN}

Jenis penelitian ini adalah penelitian pengembangan yaitu mengembangkan SPK. Penulis membagi 5 kriteria dalam menentukan alternatif penginapan menggunakan metode Promethee dengan kriteria jarak, harga, kelas penginapan, fasilitas kamar dan fasilitas pendukung.

Pengumpulan data sekunder dilakukan dengan cara membaca, mempelajari dan mengutip buku literatur, jurnal dan internet(Umar, Fadlil, et al., 2018)(Fitriana et al., 2016)(Arisandi et al., 2016).
Tahapan penelitian dalam menentukan alternatif penginapan menggunakan metode Promethee dimulai dengan menentukan masalah, menentukan bobot tiap kriteria, metode Promethee dan perhitungan menggunakan aplikasi ms.excel dan aplikasi system penentuan penginapan, seperti terlihat pada Gambar 1.

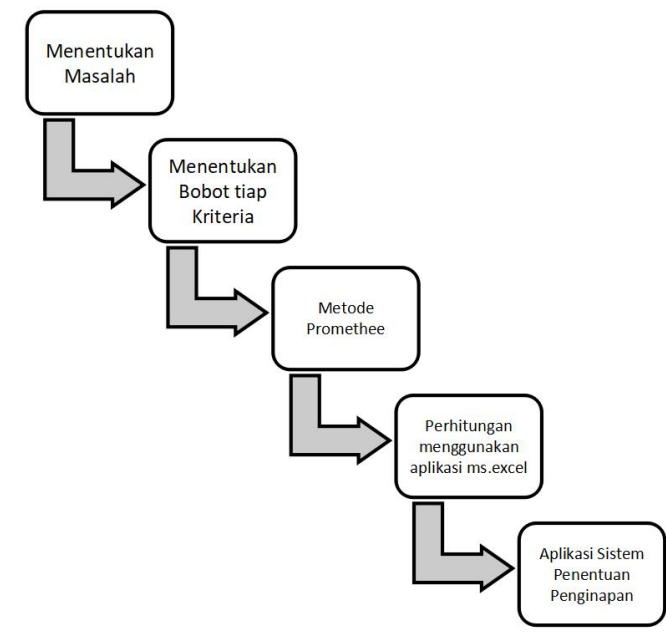

Gambar 1. Tahapan Penelitian

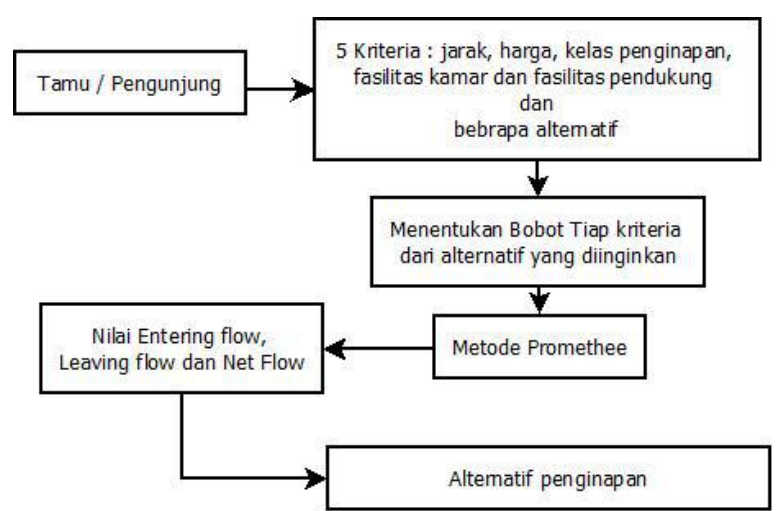

Gambar 2. Rancangan Sistem

Rancangan sistem sederhana dalam penelitian atau alur sistem sederhana yang digunakan, seperti terlihat pada Gambar 2.

Pengumpulan data dengan menentukan kriteria berdasarkan hasil literatur riview jurnal maka ditetapkan lima kriteria yang akan menjadi acuan dalam penentuan penginapan. Kriteria-kriteria tersebut dapat dilihat pada Tabel 1(Roni et al., 2019).Penentuan bobot kriteria dengan parameter dapat dilihat pada Tabel 2. 
Tabel 1. Kriteria

\begin{tabular}{lll}
\hline No & Jenis kriteria & Simbol \\
\hline 1 & Jarak & NH1 \\
2 & Harga & NH2 \\
3 & Kelas penginapan & NH3 \\
4 & Fasilitas kamar & NH4 \\
5 & Fasilitas pendukung & NH5 \\
\hline
\end{tabular}

Tabel 2. Bobot kriteria

\begin{tabular}{cl}
\hline Bobot Kriteria & Keterangan \\
\hline 5 & Sangat baik \\
4 & Baik \\
3 & Cukup \\
2 & Kurang \\
1 & Sangat kurang \\
\hline
\end{tabular}

Perhitungan secara manual dalam penelitian ini diterangkan di hasil dan pembahasan dengan kritera-kriteria untuk dilakukan proses menggunakan metode Promethee, secara sistem otomatis dengan perhitungan secara manual dengan alat bantu Ms Excel. Data yang diperlukan untuk proses adalah alternatif penginapan dan kriteria yang menghasilkan rangking (Sugianto \& Anra, 2016), alternatif penginapan selanjutnya diuji menggunakan sistem yang telah dibuat dengan bahasa pemrograman Visual Basic 2010.

\section{HASIL DAN PEMBAHASAN}

Penelitian ini diolah menggunakan aplikasi MsExcel yang selanjutnya diuji menggunakan sistem, yang ingin dicapai adalah alternatif penginapan. Data diperoleh dari literatur penginapan yang didapat dari situs online yaitu Traveloka. Data yang telah diproses dari situs tersebut sebagai contoh 5 Alternatif Penginapan (AP) dengan nilai bobot dapat dilihat pada Tabel 3.

Tabel 3. Input data alternatif

\begin{tabular}{|c|c|c|c|c|c|c|}
\hline \multirow{3}{*}{ No } & \multirow{3}{*}{ Kriteria } & \multicolumn{5}{|c|}{ Nilai alternatif } \\
\hline & & AP & AP & $\mathrm{AP}$ & $\mathrm{AP}$ & $\mathrm{AP}$ \\
\hline & & 1 & 2 & 3 & 4 & 5 \\
\hline 1 & NH1 & 5 & 3 & 4 & 5 & 4 \\
\hline 2 & NH2 & 3 & 3 & 5 & 2 & 2 \\
\hline 3 & NH3 & 3 & 4 & 2 & 5 & 3 \\
\hline 4 & NH4 & 4 & 3 & 3 & 3 & 2 \\
\hline 5 & NH5 & 3 & 2 & 3 & 1 & 1 \\
\hline
\end{tabular}

Nilai kriteria ditentukan dari data alternatif pada Tabel 3 menggunakan persamaan (1) dengan hasil yang diperoleh dapat dilihat pada Tabel 4. Tabel 4. Nilai kriteria

\begin{tabular}{llllll}
\hline & AP & \multirow{2}{*}{ AP2 } & AP3 & AP4 & AP5 \\
\hline AP1 & 1 & 1 & 1 & 0 & 1 \\
Kriteria & & 0 & 0 & 1 & 1 \\
& - & 0 & 1 & 0 & 0 \\
& & 1 & 1 & 1 & 1 \\
& & 1 & 0 & 1 & 1 \\
\hline AP2 & 0 & & 0 & 0 & 0 \\
Kriteria & 0 & & 0 & 1 & 1 \\
& 1 & - & 1 & 0 & 1 \\
& 0 & & 0 & 0 & 1 \\
& 0 & & 0 & 1 & 1 \\
\hline
\end{tabular}

\begin{tabular}{llllll}
\hline AP3 & & & & & \\
Kriteria & 0 & 1 & & 0 & 0 \\
& 1 & 1 & & 1 & 1 \\
& 0 & 0 & - & 0 & 0 \\
& 0 & 0 & & 0 & 1 \\
& 0 & 1 & & 1 & 1 \\
\hline AP4 & 0 & 1 & 1 & & 1 \\
Kriteria & 0 & 0 & 0 & & 0 \\
& 1 & 1 & 1 & - & 1 \\
& 0 & 0 & 0 & & 1 \\
& 0 & 0 & 0 & & 0 \\
\hline AP5 & 0 & 1 & 0 & 0 & \\
Kriteria & 0 & 0 & 0 & 0 & \\
& 0 & 0 & 1 & 0 & - \\
& 0 & 0 & 0 & 0 & \\
& 0 & 0 & 0 & 0 & \\
\hline
\end{tabular}

Nilai kriteria yang hasilnya ditunjukkan pada Tabel 4dihitung dengan data alternatif pada Tabel 3 menggunakan persamaan (1) dengan penjelasan:

Penginapan 1 dengan

Kriteria NH1 (baris I, kolom AP2) = jika 5 $3>=1$ maka 1 jika tidak 0 hasilnya : 1

Kriteria NH2 (baris II, kolom A2) = jika 3 $3>=1$ maka 1 jika tidak 0 hasilnya : 0

Kriteria NH3 (baris III, kolom AP2) = jika 3 $4>=1$ maka 1 jika tidak 0 hasilnya : 0

Kriteria NH4 (baris IV, kolom AP2) = jika 4 $3>=1$ maka 1 jika tidak 0 hasilnya : 1

Kriteria NH5 (baris V, kolom AP2) = jika 3 $2>=1$ maka 1 jika tidak 0 hasilnya : 1 , 
begitu seterusnya sampai kolom AP5 dan kriteria AP5.

Setelah mendapatkan nilai kriteria yang ditunjukkan pada Tabel 4. Selanjutya menghitung indeks preferensi kriteria menggunakan persamaan (3) dengan hasil ditunjukkan pada Tabel 5.

Tabel 5. Indeks preferensi kriteria

\begin{tabular}{llllll}
\hline & AP & AP & AP & AP & AP \\
& 1 & 2 & 3 & 4 & 5 \\
\hline AP1 & - & 0,6 & 0,6 & 0,6 & 0,8 \\
Kriteria & & & & & \\
\hline AP2 & 0,2 & - & 0,2 & 0,4 & 0,8 \\
Kriteria & & & & & \\
\hline $\begin{array}{l}\text { AP3 } \\
\text { Kriteria }\end{array}$ & 0,2 & 0,6 & - & 0,4 & 0,6 \\
\hline $\begin{array}{l}\text { AP4 } \\
\text { Kriteria }\end{array}$ & 0,2 & 0,4 & 0,4 & - & 0,6 \\
\hline $\begin{array}{l}\text { AP5 } \\
\text { Kriteria }\end{array}$ & 0 & 0,2 & 0,2 & 0 & - \\
\hline
\end{tabular}

Indeks preferensi kriteria dihitung dengan cara tiap baris nilai kriteria dijumlahkan dan dikalikan dengan jumlah kriteria yang hasilnya ditunjukkan pada Tabel 5 dengan nilai kriteria pada Tabel 4 menggunakan persamaan (3) dengan penjelasan:

Penginapan 2 dengan

Jumlah kriteria $\mathrm{NH}_{(1-5)}$ (baris I, kolom AP2)= $(1 / 5) \times(1+0+0+1+1)=0,6$

Jumlah kriteria $\mathrm{NH}_{(1-5)}$ (baris I, kolom AP3)= $(1 / 5) \times(1+0+1+1+0)=0,6$

Jumlah kriteria $\mathrm{NH}_{(1-5)}$ (baris I, kolom AP4)= $(1 / 5) \times(0+1+0+1+1)=0,6$

Jumlah kriteria $\mathrm{NH}_{(1-5)}$ (baris I, kolom AP5)= $(1 / 5) \times(1+1+0+1+1)=0,8$ dan begitu seterusnya sampai,

Jumlah kriteria $\mathrm{NH}_{(1-5)}$ (baris 5, kolom AP4)= $(1 / 5) \times(0+0+0+0+0)=0$

Leaving flowdihitung dengan persamaan (5) dengan indeks preferensi kriteria yang ditunjukkan Tabel 5 dengan penjelasan:

Jumlah baris AP1 kriteria dengan alternatif $(1-5)$ $=(1 /(5-1)) \times(0,6+0,6+0,6+0,8)=0,65$

Jumlah baris AP2 kriteria dengan alternatif $f_{(1-5)}$ $=(1 /(5-1)) \times(0,2+0,2+0,4+0,8)=0,4$

Jumlah baris AP3 kriteria dengan alternatif $(1-5)$ $=(1 /(5-1)) \times(0,2+0,6+0,4+0,6)=0,45$
Jumlah baris AP4 kriteria dengan alternatif $(1-5)$ $=(1 /(5-1)) \times(0,2+0,4+0,4+0,6)=0,4$

Jumlah baris AP5 kriteria dengan alternatif $f_{(1-}$ $5)=(1 /(5-1)) \times(0+0,2+0,2+0)=0,1$

Entering flow dihitung dengan persamaan (4) dengan indeks preferensi kriteria yang ditunjukkan Tabel 5 dengan penjelasan:

Jumlah kolom AP1 dan APkriteria ${ }_{(1-5)}=(1 /$ (51)) $\mathrm{x}(0,2+0,2+0,2+0)=0,15$

Jumlah kolom AP2 dan APkriteria ${ }_{(1-5)}=(1 /$ (51)) $\mathrm{x}(0,6+0,6+0,4+0,2)=0,45$

Jumlah kolom AP3 dan AP kriteria $(1-5)=(1 /$ (51)) $\mathrm{x}(0,6+0,2+0,4+0,2)=0,35$

Jumlah kolom AP4 dan APkriteria $(1-5)=(1 /(5-$ 1)) $\mathrm{x}(0,6+0,4+0,4+0)=0,35$

Jumlah kolom AP5 dan AP kriteria $(1-5)=(1 /(5-$ 1)) $\mathrm{x}(0,8+0,8+0,6+0,6)=0,7$

Net flow dihitung dengan persamaan (6) dengan leaving flowdikurangi entering flow untuk mendapatkan nilai net flow yang ditunjukkan pada Tabel 6 .

\begin{tabular}{llll}
\multicolumn{4}{c}{ Tabel 6. Nilai net flow } \\
\hline & $\begin{array}{l}\text { Leavin } \\
\text { g flow }\end{array}$ & $\begin{array}{l}\text { Enterin } \\
\text { g flow }\end{array}$ & $\begin{array}{l}\text { Net } \\
\text { flow }\end{array}$ \\
\hline $\begin{array}{l}\text { AP } \\
1\end{array}$ & 0,65 & 0,15 & 0,5 \\
\hline $\begin{array}{l}\text { AP } \\
2\end{array}$ & 0,4 & 0,45 & $-0,05$ \\
\hline $\begin{array}{l}\text { AP } \\
3\end{array}$ & 0,45 & 0,35 & 0,1 \\
\hline $\begin{array}{l}\text { AP } \\
4\end{array}$ & 0,4 & 0,35 & 0,05 \\
\hline AP & 0,1 & 0,7 & $-0,6$ \\
5 & & & \\
\hline
\end{tabular}

Implementasi pada penelitian ini menggunakan tampilan sistem antarmuka SPK penentuan penginapan.

Halaman antarmukaloginterdiri dari username dan passwordseperti pada Gambar 3. 


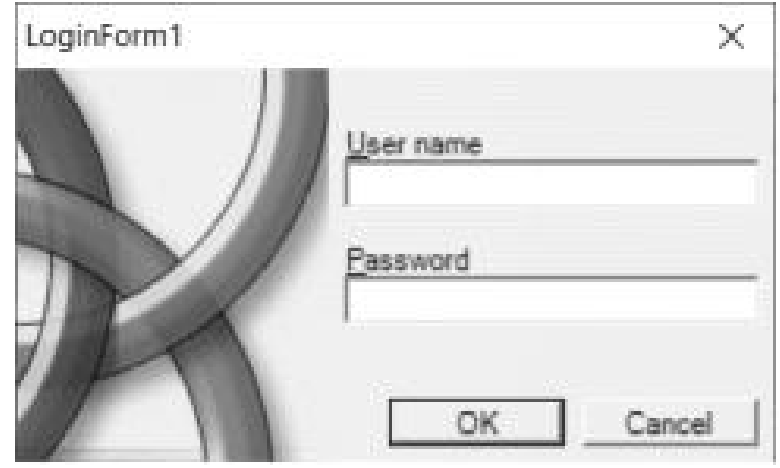

Gambar 3. Antarmuka Halaman Login Halaman antarmuka utamaterdiri dari menu perhitungan menggunakan Promethee seperti pada Gambar 4.

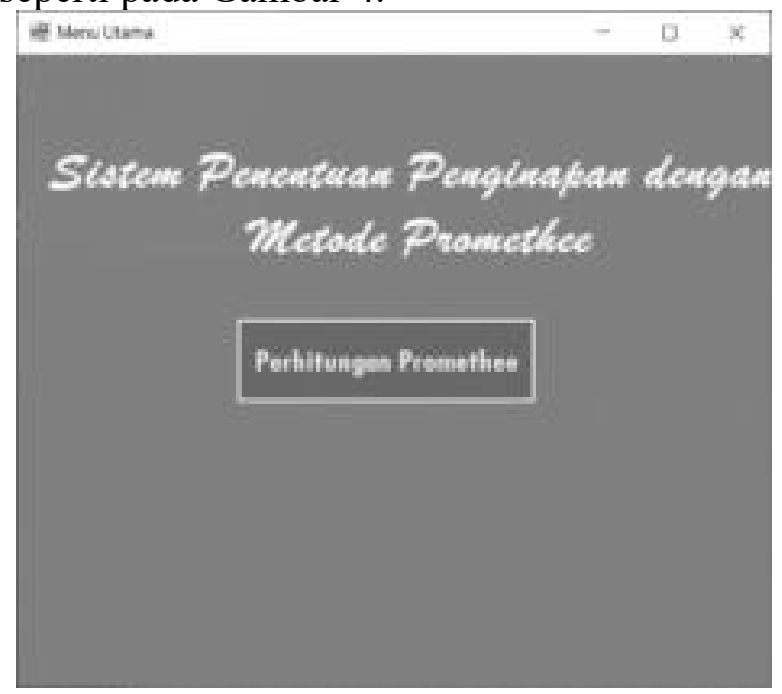

Gambar 4. Antarmuka Halaman Utama

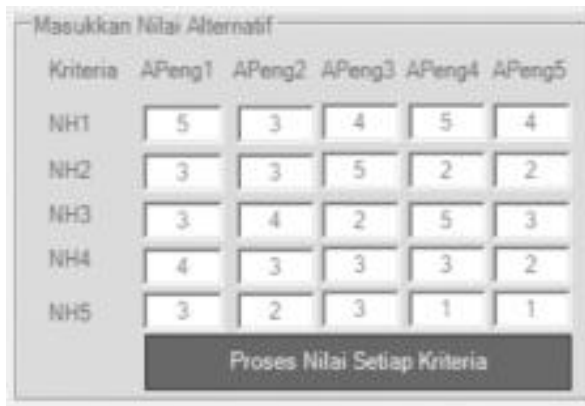

Gambar 5. Antarmuka Input Nilai

Halaman antarmuka perhitungan prometheeterdiri dari menu masukan nilai alternatif (Gambar 5), menghitung nilai kriteria (Gambar 6), menghitung indeks preferensi kriteria (Gambar 7), leaving flow(Gambar 8), entering flow(Gambar 9), dan net flow(Gambar $10)$.

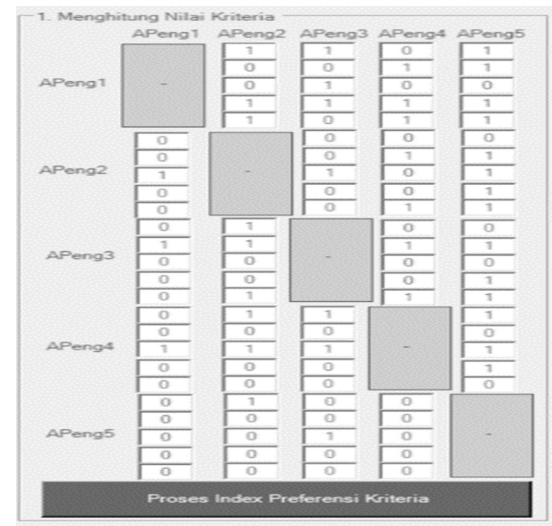

Gambar 6. Antarmuka Perhitungan Nilai Kriteria

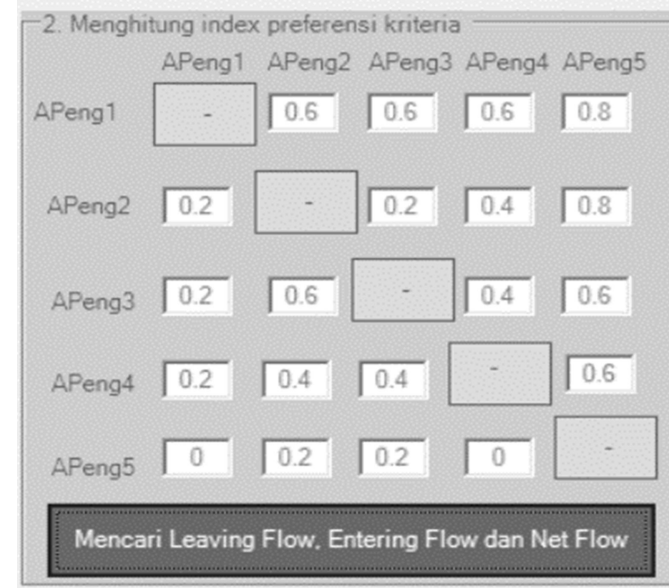

Gambar 7. Antarmuka Perhitungan Indeks Preferensi Kriteria

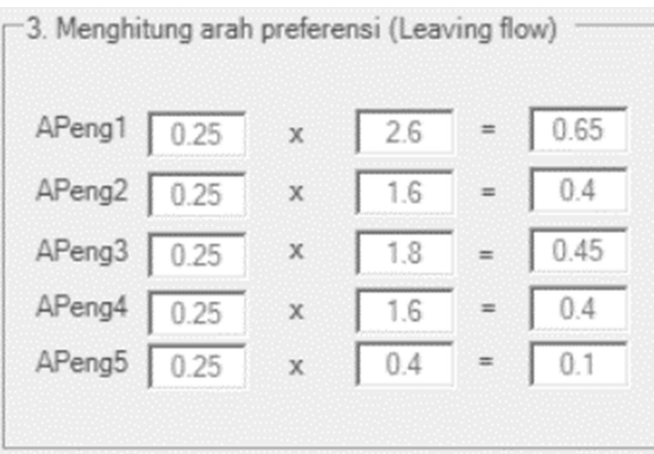

Gambar 8. Antarmuka leaving flow

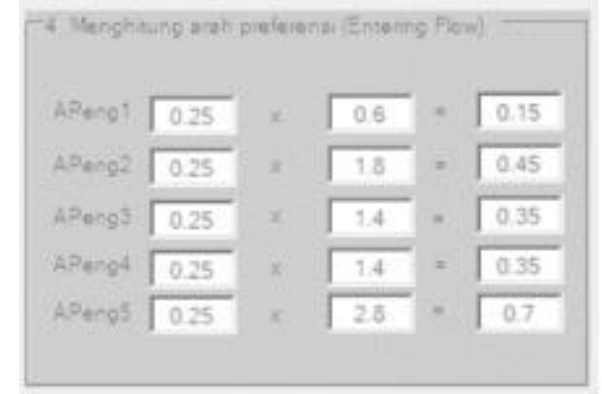

Gambar 9. Antarmuka entering flow

Gambar 10. Antarmuka net flow 
Hasil dari perhitungan menggunakan metode Promethee nilai net flow Ms Excel pada Tabel 6 dan menggunakan sistem dengan nilai net flow pada Gambar 10 hasilnya sama tidak ada perbedaan. Jika diurutkan rangking alternatif dapat dilihat pada Tabel 7. Nilai paling tertinggi sebesar 0,5 adalah alternatif penginapan 1 dengan ini lebih diprioritaskan sesuai dengan kriteria yang diinginkan oleh pengunjung.

Tabel 7. Rangking alternatif

\begin{tabular}{lll}
\hline Rangking & Alternatif & $\begin{array}{l}\text { Net } \\
\text { Flow }\end{array}$ \\
\hline 1 & APenginapan1 & 0,5 \\
\hline 2 & APenginapan3 & 0,1 \\
\hline 3 & APenginapan4 & 0,05 \\
\hline 4 & APenginapan2 & $-0,05$ \\
\hline 5 & APenginapan5 & $-0,6$ \\
\hline
\end{tabular}

\section{KESIMPULAN}

Penelitian ini menghasilkan aplikasi untuk membantu dalam menentukan penginapan menggunakan bahasa pemrograman Visual Basic dengan menggunakan metode Promethee. Sistem ini memperoleh alternatif berupa rangking penginapan yang sama dengan perhitungan manual Ms Excel.

\section{SARAN}

Perlu dilakukan penelitian lain dengan membandingkan metode Promethee dengan metode lain dan memperbanyak fitur-fitur sehingga mempermudah dalam menghitung menggunakan sistem.

\section{UCAPAN TERIMA KASIH}

Saya ucapkan terima kasih kepada Allah Yang Maha Penyayang sehingga saya diberikan kesehatan untuk mengerjakan penelitian ini. Terima kasih kepada pembimbing 1 dan 2 yang membantu artikel ini selesai. Tidak lupa kepada orang tua dan teman-teman MTI8 yang selalu membantu baik moral maupun materil dan penyemangat saya.

\section{DAFTAR PUSTAKA}

Anjasmaya, R., \& Andayani, S. (2018). Sistem
Pendukung
Keputusan
Penentuan
Komoditi
Sayuran
Berdasarkan
Karakteristik Lahan Menggunakan
Metode Promethee. Juita, 6(2), 127-135.

Aprilia Triase; Sriani, Sriani, R. T. (2017). Penentuan Tempat Menginap Dengan Menggunakan Fuzzy Multiple Attribute Decision Making. Algoritma : Jurnal Ilmu Komputer Dan Informatika, 1(1), 30-34. Http://Jurnal.Uinsu.Ac.Id/Indeks.Php/Alg oritma/Article/View/1306

Arisandi, Sarita, M. I., \& Sagala, L. O. H. (2016). Sistem Penunjang Keputusan Pemilihan Hotel Di Kota Kendari Menggunakan Metode Fuzzy Tahani Berbasis Web. Semantik, 2(1), 331-340.

Ayu Septiana Sari, Jumadil Nangi, R. R. (2016). Penerapan Metode Promethee Dalam Sistem Penunjang Keputusan Penentuan Penerima Beasiswa Bidik Misi Universitas Halu Oleo. Semantik, 2(2), 229-236.

Fitriana, Y., Umar, R., \& Sunardi. (2016). Analisis Perbandingan Metode Simple Additive Weighting (Saw) Dan Metode Decison Table Pada Sistem Pendukung Keputusan. Cyber Learning \& It Computer Karawang, 1(1), 2014-2017.

Gusrianty, G., Oktarina, D., \& Kurniawan, W.

J. (2019). Sistem Pendukung Keputusan Dengan Metode Promethee Untuk Menentukan Kepuasan Pelanggan Penjualan Sepeda Motor Bekas. Sistemasi, $8(1)$,

Https://Doi.Org/10.32520/Stmsi.V8i1.419

Hidayat, R. (2016). Menentukan Promosi Jabatan Karyawan Dengan Menggunakan Metode Profile Matching Dan Metode Promethee. Ijse - Indonesian Journal On Software Engineering, 2(1), 57-65. Http://Ejournal.Bsi.Ac.Id/Ejurnal/Indeks.

Php/ljse/Article/View/667/558

Imandasari, T., \& Windarto, A. P. (2017). Sistem Pendukung Keputusan Dalam Merekomendasikan Unit Terbaik Di Pdam Tirta Lihou Menggunakan Metode Promethee. Jurnal Teknologi Dan Sistem Komputer, 5(4),

Https://Doi.Org/10.14710/Jtsiskom.5.4.20 17.159-165

Larasati, E., Hamdana, E. N., \& Hutami, A. M. (2019). Implementasi Metode Ahp Dan Promethee Pada Spk Pemilihan Hotel. Jip (Jurnal Informatika Polinema), 6(1), 49- 
54.

Mesran, Suginam, \& Hildayani, S. (2019). Sistem Pendukung Keputusan Kelayakan Peserta Lelang Tender Pemerintah Menerapkan Promethee Ii. Jurnal Teknovasi, 06(1), 17-24.

Ningsih, S. R., \& Windarto, A. P. (2018). Penerapan Metode Promethee Ii Pada Dosen Penerima Hibah P2m Internal. Infotekjar (Jurnal Nasional Informatika Dan Teknologi Jaringan), 3(1), 20-25. Https://Doi.Org/10.30743/Infotekjar.V3i1. 641

Pasaribu, Y. S. (2019). Sistem Pendukung Keputusan Pemilihan Hotel Bintang Lima Terbaik Di Kota Medan Menggunakan Metode Promethee. In Jurnal Pelita Informatika (Vol. 18, Issue 1).

Pramudhita, A. (2017). Sistem Pendukung Keputusan Pemilihan Rumah Kost Putra Untuk Mahasiswa Di Kota Malang Dengan Menggunakan Metode Saw. Jurnal Mahasiswa Teknik Informatika, 1(1), 906-912.

Roni, R., Sumijan, S., \& Santony, J. (2019). Metode Weighted Product Dalam Pemilihan Penerima Beasiswa Bagi Peserta Didik. Jurnal Resti (Rekayasa Sistem Dan Teknologi Informasi), 3(1), 87-93.

Https://Doi.Org/10.29207/Resti.V3i1.834

S, Gde Iwan Widnyana, I. G. (2018). Sistem Pendukung Keputusan Seleksi Calon Karyawan Baru Menggunakan Metode Promethee Berbasis Web Pada Pt. Asuransi Wahana Tata Sales Office Denpasar. Jurnal Manajamen Dan Teknologi Informasi, 8(2).

Sabrina, P. N. (2017). Analytic Hierarchy Process Dengan Multi-Level Kriteria Pada Sistem Pemilihan Hotel. Seminar Nasional Informatika Dan Aplikasinya (Snia) 2017 Cimahi, September, 56-62.

Sofhian, Sujaini, H., \& Pratiwi, H. S. (2016). Dosen Terbaik Menggunakan Metode Promethee ( Studi Kasus: Teknik Informatika Universitas Tanjungpura ). Jurnal Sistem Dan Teknologi Informasi (Justin), 1(1), 1-6.

Sugianto, H., \& Anra, H. (2016). Sistem
Pendukung Keputusan Pemilihan Tempat Kost Khusus Mahasiswa Dengan Metode Ahp Dan Topsis Berbasis Web ( Studi Kasus: Kota Pontianak ). Jurnal Sistem Dan Teknologi Informasi (Justin) Vol., 1(1), 1-6.

Ternando, A. J., Efendi, R., \& Purwandari, E. P. (2018). Sistem Pendukung Keputusan Dalam Pemilihan Penginapan Di Kota Bengkulu Menggunakan Metode Simple Additive Weighting (Saw) (Studi Kasus : Kota Bengkulu). Jurnal Rekursif, 6(1), 24-35.

Umar, R., Fadlil, A., \& Yuminah. (2018). Sistem Pendukung Keputusan Dengan Metode Ahp Untuk Penilaian Kompetensi Soft Skill Karyawan. Khazanah Informatika |Issn:, 4(1), 27-34.

Umar, R., Sunardi, \& Fitriana, Y. (2017). Taxonomy Of Decision Support System Based On Software And Calculation Method. International Journal Of Innovative Science And Research Technology, 2(9), 206-211.

Umar, R., Sunardi, \& Fitriana, Y. (2018). Taxonomy Of Fuzzy Multi-Attribute Decision Making Systems In Terms Of Model , Inventor And Data Type. Engineering, Technology \& Applied Science Research, 8(1), 2568-2571.

Wardhani, U., \& Nur, M. A. (2017). Sistem Pendukung Keputusan Pemilihan Tempat Kos Untuk Mahasiswa Di Luwuk Banggai Dengan Metode Saw (Simple Additive Weighting). Jtriste, 4(1), 9-14.

Widyastuti, M., Samosir, F. R. S., Windarto, A. P., \& Hartama, D. (2019). Implementasi Metode Promethee Dalam Pemilihan Kenaikan Jabatan Sous Chef Menjadi Chef. Teknologi Komputer \& Sains, 1(1), 807-812.

Yudha, H. A., Yuwono, B., \& Kodong, F. R. (2016). Sistem Pendukung Keputusan Menggunakan Metode Promethee (Studi Kasus: Stasiun Pengisian Bahan Bakar Umum). Telematika, 8(1). Https://Doi.Org/10.31315/Telematika.V8i 1.444 